\title{
Mobile Application Purchase: Comparison of Utilitarian Features between Users and Non-users
}

\author{
Emad Rahmanian $^{\mathrm{a}}$ \& Hassan Abolmolouki ${ }^{\mathrm{a}}$
}

aUniversity of Tehran, Tehran, Iran

\begin{abstract}
This study aims to understand how utilitarian features of a mobile application moderate purchase motivations and intentions among users and non-users. Taking a case of cinema ticket purchase in the Iranian context, this study has collected empirical data through a questionnaire from 240 respondents. Multiple regression analysis was used to analyze data. Motivational variables were grouped into four groups: functional motivations, convenience-based functional motivations, product motivations, and service motivations. In addition, the gender issue of the consumer was also considered. This study finds that such motivational factors significantly affect consumers' motivations, both male and female consumers. Analysis on gender shows no significant differences among male and female consumers. Therefore, these factors should be considered in formulating marketing communication strategy and media management, especially for non-users. Further research should consider other motivational factors, such as hedonic motivations, attitude, and situational factors, to understand consumer behaviors comprehensively.
\end{abstract}

Keywords: marketing communication, mobile application, mobile purchase, utilitarian features, mobile marketing, cinema ticket.

\section{Article History}

Received: 10 April 2021

Revised: 20 August 2021

Accepted: 10 November 2021

\section{Introduction}

Traditional online retail channels are changing towards a rapidly emerging new channel, mobile retail channel. Today consumers use smartphones to search for products and services, compare features and prices, and purchase. This purchase might be through the company website or mobile applications, which might be an official application or a third-party application. This change is bilateral; retailers now have access to consumers and are able to offer them products or promotions through a new channel. One might get an offer through notifications on a mobile phone even when the application runs in the background. 
The number of internet users in Iran has sharply increased in recent years. Nowadays, according to the Ministry of Information and Communication Technology of Iran, almost 80 percent of Iranians have access to the internet. Additionally, 60 percent of Iranian use smartphones. Internet usage had a sharp growth in Iran which can be linked to economic growth in recent years after Iran's nuclear deal (JCPOA). The internet penetration rate combined with the abundance of smartphones among Iranian users presents a new shopping model. Like many other countries, the travel industry and retailing were the first industries to benefit from this phenomenon.

Cinema e-ticketing was among the second wave of online businesses in Iran to adapt to this new purchase form. In addition, price is an essential factor in purchase decisionmaking; other factors encouraged Iranians to buy online tickets. The Iranian box office was near doubled in less than three years. In this context, understanding the factors and motivation of Iranian consumers for an online purchase is very important.

Today one of the biggest challenges for companies is encouraging and persuading consumers to purchase e-tickets through mobile devices. E-ticket shopping is not a relatively new domain but still has several shortcomings related to consumers' behaviour and technology. The technological shortcomings are, for example, small screen sizes and the unavailability of internet coverage (Kumar \& Mukherjee, 2013). These shortcomings are to be improved by applying new technologies such as folding screen and $5 \mathrm{G}$ technology. Nevertheless, other imperfections such as limited understanding of consumer behaviour in mobile channels might need further study.

Thus, the prevalence of mobile phone usage has created an unprecedented opportunity for companies. Everyday use of mobile phones provides a fertile ground for marketing efforts and strategies. However, research on mobile marketing and channel has primarily focused on the role of technology and neglected the part of consumers in the field. This paper tries to focus on the mobile track and the role of individuals in using it. Therefore, this paper aims to understand different constructs of consumers' utilitarian motivations for online cinema ticket purchase through mobiles. The applied method is quantitative, and the outcome of this study might shed some light on consumers' expectations from an online purchase and reservation system, which might apply to other sections of the service industry that share the characteristics of the cinema industry. 


\section{Literature review and conceptualization}

This study will examine how utilitarian features motivate consumers to buy a cinema ticket through a mobile application. Mobile channels and applications have changed consumer behavior (Park \& Lee, 2017). This rise of mobile shopping might collide with the traditional online retailing system (Verhoef et al., 2015). But little is known about how consumers are motivated to use mobile channels to buy products and services. People use technology for different reasons; therefore, various features might encourage them.

\section{a. Mobile channel and marketing communication}

In the last decade, the meaning of the term mobile has changed fundamentally, and now it encompasses devices and services (Tong et al., 2020). Mobile marketing is defined as "the two-way or multi-way communication and promotion of an offer between a firm and its customers using a mobile medium, device, or technology" (Shankar \& Balasubramanian, 2009). Many scholars have argued and studied the differences between e-commerce and mobile commerce and marketing (Wu \& Hisa, 2008). This difference is due to differences in key features, the value proposition of mobile marketing, such as ubiquity, convenience, personalization, localization, flexibility, spontaneity, immediacy, accessibility, time-criticality, and instant connectivity (Clarke III, 2001; Denk \& Hackl, 2004; Mort \& Drennan, 2002). Shankar and Balasubramanian (2009) argue that mobile marketing is interactive. Due to the recent changes in consumer behaviors and trends, such features are becoming more critical in today's dynamic environment (Bolton \& SaxenaIyer, 2009; Deighton \& Kornfeld, 2009).

Within the field of marketing communication studies, especially with the new perspective of integrated marketing communication, this kind of mobile marketing communication has become one of the central marketing communications means. This mobile marketing communication helps to reach the objectives of communication, namely disseminating information (informative communication), influencing people to make purchases or attracting consumers (persuasive communication), and reminding audiences to repeat the purchases (recalling communication).

Although the mobile channel concept is not much new and dates back to 2002 (Pedersen et al., 2002), it has recently become the prominent alternatives for other retail channels (Groß, 2015; Holmes et al., 2013). Many major companies have developed their application and have modified their websites to be compatible with mobile phones. Online and mobile shopping combine the availability of a product, service, information, and 
means of payment. However, mobile shopping has a significant difference from online shopping, as it is not limited to location, directly influencing purchasing and informationrelated activities (Taylor \& Levin, 2014). Initial studies showed an increase in shopping through mobile (Holmes et al., 2013) based on hedonic and utilitarian motivations, similar to any other purchase. According to this view, utilitarian performance expectations motivate consumers to choose mobile channels as their desired channel (Yang, 2010). Some works suggest that since youth have more mobile purchase experience, they tend to use mobile for shopping more (Bigne et al., 2005), and others reject this notion (Park \& Lee, 2017).

Mobile shopping gained more popularity among consumers; it was considered the organic growth of internet marketing and channel (Hinz et al., 2011). But later, it became evident that mobile purchase adoption increases the order size and rate; and motivates low-income consumers to spend more (Wang et al., 2015). As this research stream gained more attention, some studies questioned these findings and asserted that it is merely a consumer shift from one channel to another (Huang et al., 2016). Mobile channel also provides consumers with other possibilities such as checking prices, comparing products and gathering information, and reading consumers' reviews (Verhoef et al., 2009).

Finally, previous researches in the mobile purchase and mobile channels do not cover the consumers' motivation. Understanding consumer behavior is crucial for managing and developing a successful mobile channel (Hung et al., 2012). This paper investigates this aspect of the mobile channel and incorporates utilitarian motivations in mobile purchase literature.

\section{b. Consumer motivations}

While the mobile channel is removing spatial and temporal limitations of traditional retail channels (Demirkan \& Spohrer, 2014; Pantano, 2014), utilitarian and hedonic motivation becomes an influential factor in decision making (Bigne et al., 2005; Wu \& Wang, 2005). Consumers' lifestyles and channel choices have changed over the past decade and mobile shopping is one of the most influential factors that inducing this change. Mobile shopping has become increasingly important in today's life (Wang et al., 2015; Yang \& Kim, 2012). Mobile shopping is a relatively new important trend that provides an excellent potential for both businesses and marketers. The mobile technology has changed consumers' interaction with companies. The most important feature of mobile shopping is availability. Smartphones with access to high-speed internet enable consumers to browse for services and products or use an application to purchase through different retailers. 
Channel choice has been subject to study in the forms of multi-channel choice focusing on different substrata. Different scholars studied various factors affecting channel choices, such as specific products, namely CD and PC (Frasquet et al., 2015), and technology acceptance model (Keen et al., 2004), to understand the consumers' motivation. Other studies focused on product category, price, distance (Thomas \& Sullivan, 2005), sociodemographic, user experience, and communication (Ansari et al., 2008). Considering the prevalence and prominence of the mobile channel, these researches have limited relevance. Mobile channel is not incorporated in most of them; therefore, it justifies the examination of mobile media. Furthermore, this research emphasizes utilitarian motivations to understand how they motivate consumers to buy through mobile channels.

Different channels have different consumer motivations (Elastick \& Feinberg, 1999; Parsons, 2002; Westbrook \& Black, 1985), and naturally, reasons might vary according to the features of the channel (Arnold \& Reynolds, 2003; Scarpi, 2005). The main difference between the mobile application and online shopping channels is availability. Mobile application is available as people are on the go and is not temporally or spatially limited (Heinonen \& Pura, 2006). This ubiquitous channel provides consumers with exciting features such as localization and personalization, which might affect their motivations unprecedented in other forms of traditional channels.

There are many motivations in shopping, but most scholars consider utilitarian and hedonic values central to consumer purchase behavior because they encompass the most basic construct of the consumption phenomenon (Babin et al., 1994). Consumer motivation is related to problem-solving or searching for arousal and sensory stimulation (Hirschman \& Holbrook, 1982). This dichotomy has been studied in the shopping context as related to work (Fischer \& Arnold, 1990; Sherry et al., 1993) or fun (Babin et al., 1994; Bloch \& Bruce, 1984; Sherry, 1990).

In a utilitarian view, the primary concern of consumers is to fulfill the purchase process efficiently and timely without any further problems (Childers et al., 2001). While in hedonistic behavior, other motivations such as adventure (Sherry, 1990) are central to behavior. Consumers value the enjoyment aroused from the experiences rather than achieving any goals (Hirschman \& Holbrook, 1982). Utilitarian shopping motivations are those behavior influenced by functional aspects of the product or service (Kim, 2006). Previous studies in this area point out that efficiency and achievement are among the factors affecting consumers' perception of functionality (Babin et al., 1994; Kim, 2006), and the motivations for purchasing products quickly and easily. As we mentioned 
beforehand, the availability of mobile shopping is the main characteristic of this type of shopping which consumers highly value (Grewal et al., 2003; Mathwick et al., 2001).

The functionality of motivation has been studied before (Sheth, 1983; Tauber, 1972). But more recently, functional aspects of online purchase, such as convenience, product variety, and accessibility, gained popularity as a research topic (Alba et al., 1997; Donthu \& Garcia, 1999; Wolfinbarger \& Gilly, 2001). Based on previous works on online purchase motivations, three categories of motivation were selected: functional, product, and service motivations.

\section{i. Functional motivations}

Functional motivations might take several forms in which the practicality of the purchase is evaluated. For example, convenience is among the most fundamental states of functional motivation. It is safe to say the primary reason for an online purchase is convenience, in the form of time, place, and the purchase process (Alreck \& Settle, 2002; Foucault \& Scheufele, 2002; Mohd Suki et al., 2008).

Cinema ticket purchase applications enhance these types of convenience, which may motivate consumers to purchase tickets through mobile applications. Also, there is empirical evidence that those motivated by convenience are more likely to use online channels to buy their desired services or products (Bhatnagar et al., 2000; Paul et al., 2010)

According to Technology Acceptance Model (TAM), consumers are more likely to adopt those technologies that are easy to use and understand (Dabholkar \& Bagozzi, 2002; Davis et al., 1989; Perea y Monsuwé et al., 2004). Availability of services offered through mobile applications provides an easy solution for consumers' need for ease of use which consequently motivates the consumer to purchase online (Burke, 2002; Evanschitzky et al., 2004; Foucault \& Scheufele, 2002; Rajamma et al., 2007). Online purchase of cinema tickets eliminates several problems. These include the need for transportation for purchase, the probability of waiting for lines and being sold out, influencing channel preference and purchase behavior, future intentions, and recommendation decisions (Newman et al., 2018).

Thus, based on these literature reviews, we assert that these convenienceoriented features motivate consumers to purchase tickets using mobile applications (H1). 


\section{ii. Product motivations}

Purchasing tickets through an application with a few taps while on the go or chatting with friends is something relatively new. The consumer now can buy tickets for movie theaters across the city, which they usually would not go. Online and mobile purchase is not constrained locally, temporally, or spatially. With the current trend of mobile uses instead of desktop computers, availability encourages consumers to use the applications instead of websites or mobile browsers. Other findings also point out that the ability to find the right product at the right time and being able to purchase at the same time increases consumers' motivation to purchase through mobile applications (Yang \& Kim, 2012).

Early studies on product motivation revealed that consumers tend to certain products online, such as books, CDs, and tickets. This is due to the nature of these products. Consumers do not feel wary about the quality of books or tickets while buying online (Perea y Monsuwé et al., 2004), and they know "they get what they buy". This certainty for the quality of the product motivates consumers to purchase tickets online or through applications. Unlike the traditional purchase process, online shopping and mobile application allow the consumer to consider many options. While buying tickets at a movie theater or multiplex limits the available options to those movies on their schedule, applications provide a wide variety of films and theaters in one place.

Hence, we can hypothesize that features of mobile applications (here product motivation) motivate consumers to purchase tickets (H2).

\section{iii. Service motivations}

Service is a motivation for online purchases, which is perceived in the form of value (Perea y Monsuwé et al., 2004). This motivation is based upon the foundation that accessibility is the key factor for online purchase, and an application must give access to products as much as possible (Holmes et al., 2013). Accessibility must include access to products and services and different types of information. These features of accessibility are offered through mobile applications.

Besides accessibility, timeliness is another factor. The delivery of a purchased product at once might serve as a motivating factor in the case of a cinema ticket (Perea y Monsuwé et al., 2004). Receiving tickets as CR code, SMS, or a digit code that could be inserted into a printer at a movie theater gives excellent accessibility to the product. This fast delivery motivates consumers to buy online (Rajamma et al., 2007). 
Consumer in the mobile purchase even can choose their desired seats according to their preferences and can, in some cases, book a parking lot. These types of accessibilities are not available in a traditional purchase.

Knowing that one can browse through different movies and movie theaters, purchase and pay online, all with collateral benefits such as desired seats and booked parking lot, prompts another factor, reliability. Consumers seek a reliable service through an application, and if they are sure of that quality, it might motivate them to purchase online. Reliable solutions to queries and smooth transactions are associated with the online purchase (Rajamma et al., 2007). We assume that these features significantly motivate consumers $\left(\mathrm{H}_{3}\right)$. These theoretical conceptualizations are depicted in Figure 1.

\section{c. Gender and media selection}

Although gender issues are not among the motivational factors, the data might provide an opportunity to study them. Many recent studies pointed out that in mobile shopping men and women are influenced by different factors (Bigne et al., 2005; Hahn \& Kim, 2013). This study tries to shed light on this factor as well.

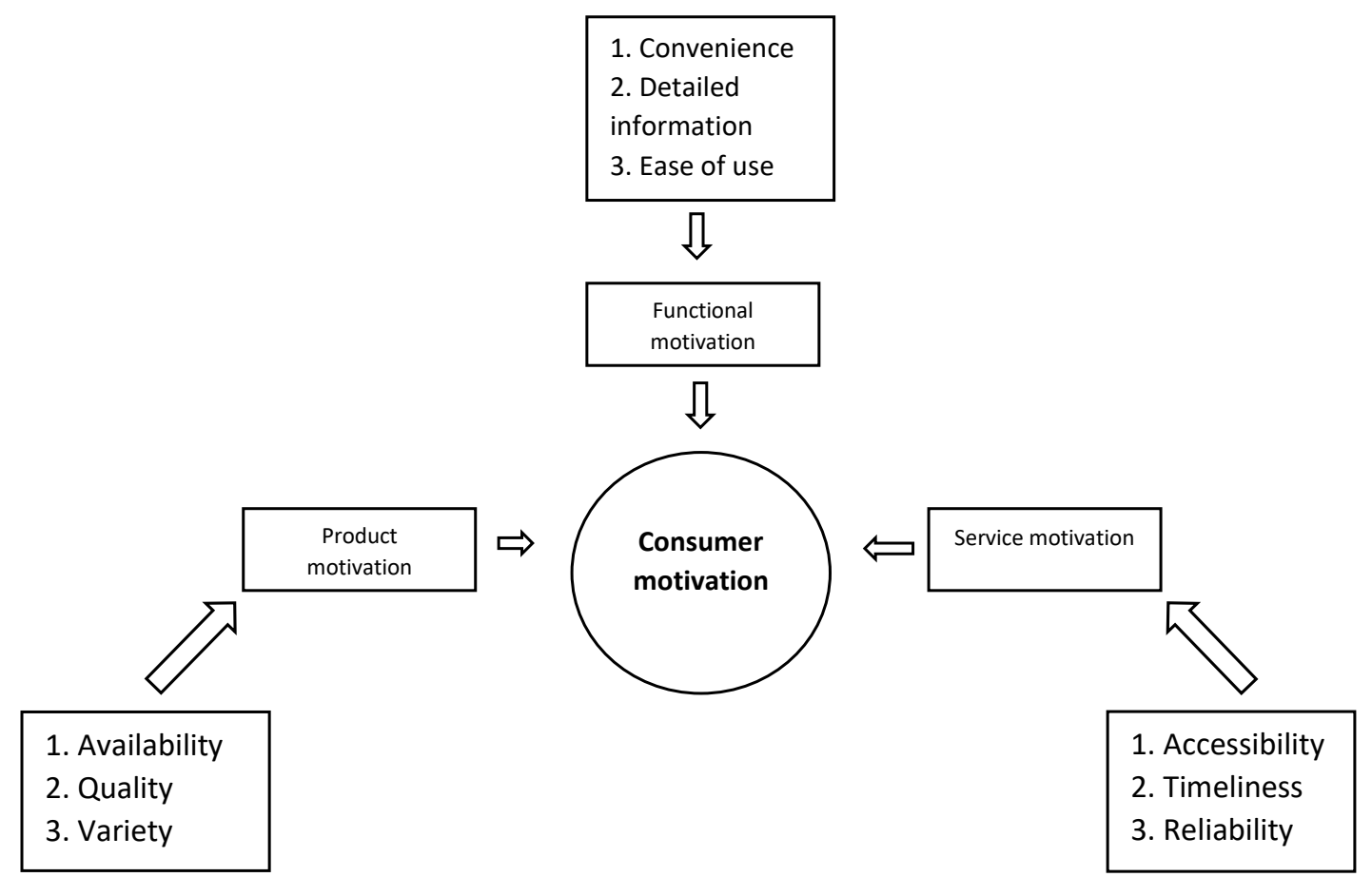

Figure 1. Conceptualization of motivational factors 


\section{Research design and method}

Mobile shopping has been studied for almost two decades. Motivation is a complex notion and is better understood through different views of consumers on the subject. The central assumption of this paper is that the ability to purchase through mobile applications has boosted the purchase of cinema tickets because of the utilitarian features they provide.

One major domestic application was chosen for this study, namely Cinema-ticket. This application has been installed on more than 360.000 smartphones and is available in Google play and two domestic marketplaces: Mayket and Bazar. All the movie theaters in Tehran are accessible through this application. It enables consumers to find out information on movies, box offices, movie theaters. Consumers are able to buy or reserve tickets and select their desired seats. In some movie theaters, it is possible to book a parking lot as well. After completing the purchase process, a code is sent to the consumer to be encoded into the interactive printer at movie theaters in order to receive the tickets.

This paper has descriptive, diagnostic nature and aims to examine the motivations of consumers for choosing a mobile channel for purchasing cinema tickets. The research methodology consists of a review of academic literature presented before and an empirical study consisting of a questionnaire and consequent analysis.

\section{a. Questionnaire development}

The questionnaire is based on a literature review. In order to increase the ease of answering, Likert five scale questions were presented to respondents through tablets. They could select the answers by tapping on the screen and selecting next to see the next question. The questionnaire consists of two parts: demographic questions and constructs questions. Three constructs are summarized in Table 1.

Table 1. Questionnaire constructs

\begin{tabular}{|c|c|c|c|}
\hline Variable & Constructs & References & $\begin{array}{c}\text { No. of } \\
\text { questions }\end{array}$ \\
\hline $\begin{array}{l}\text { Functional } \\
\text { Motivations } \\
(\mathrm{FM})\end{array}$ & $\begin{array}{l}\text { Convenience, detailed } \\
\text { information, ease of } \\
\text { use }\end{array}$ & $\begin{array}{l}\text { Alreck and Settle } \\
\text { (2002); Foucault and } \\
\text { Scheufele (2002); Mohd } \\
\text { Suki et al. (2008); Paul } \\
\text { et al. (2010) }\end{array}$ & 10 \\
\hline $\begin{array}{l}\text { Product } \\
\text { Motivations } \\
(\mathrm{PM})\end{array}$ & $\begin{array}{l}\text { Availability, quality, } \\
\text { variety }\end{array}$ & $\begin{array}{l}\text { Perea y Monsuwé et al. } \\
\text { (2004); Yang and Kim } \\
\text { (2012) }\end{array}$ & 8 \\
\hline $\begin{array}{l}\text { Service Motivations } \\
(\mathrm{SM})\end{array}$ & $\begin{array}{l}\text { Accessibility, } \\
\text { timeliness, reliability }\end{array}$ & $\begin{array}{l}\text { Holmes et al. (2013); } \\
\text { Perea y Monsuwé et al. } \\
\text { (2004); Rajamma et al. } \\
(2007)\end{array}$ & 8 \\
\hline
\end{tabular}




\section{b. Data collection}

In the data collecting step, some cinemas in Iran were selected to distribute the questionnaires. There are 56 multiplex and multi-theater cinemas in Tehran, with 143 theaters and a combined capacity of 309.837 seats. To disseminate the questionnaires, 22 multiplexes were selected, each scattered geographically in every municipal district of Tehran. Random sampling was used on all days of the week. We observe schedules, movie types, and consumers at the cineplex for two weeks to obtain the largest possible sample.

Following the recommendations and methods of Gerbing and Anderson (1988), it was tried to reach a sample of 300 people, and it was divided into two groups. In the first phase, mobile purchasers were selected to complete the questionnaire, and from a total of 146 completed questionnaires, 120 questionnaires were acceptable (Table 2).

Table 2. Descriptive statistics for purchasers

\begin{tabular}{lll}
\hline & Groups & Number (\%) \\
\hline Gender & Female & $58(48 \%)$ \\
& Male & $62(52 \%)$ \\
\hline Age & under 19 & $34(28)$ \\
& 20 to 29 & $45(38)$ \\
& 30 to 39 & $22(18)$ \\
& 40 to 49 & $11(9)$ \\
& above 50 & $8(7)$ \\
\hline
\end{tabular}

To duplicate the demographic profile of purchasers for non-purchasers, purposeful sampling was used. Repeating the first phase, 120 questionnaires out of about 200 were selected. Both samples have precisely the same profile. To ensure that non-user respondents understood the mobile application, they were asked to work with it on a tablet. Also, the whole process of online purchase was explained in detail. For nonpurchaser, some questions were omitted.

\section{c. Construct analysis}

The data was analyzed using SPSS 19. The statistical analyses are descriptive, including causal multivariate techniques. The factor analysis grouped items into four constructs with 32 items. Principal factor analysis was employed to analyze the data and extract items into a group. Four groups were identified: Functional Motivations (FM), Convenience Based Functional Motivations (CBFM), Product Motivations (PM), and Service Motivations (SM). The sample met the criteria for factor loading (factor loading above 0.5 , at least 50 
responses, and five responses for every variable). The reliability of each item and the composite reliability of each construct are calculated and presented in Table 3 .

Table 3. Analysis of factorial validity and construct reliability

\begin{tabular}{|c|c|c|}
\hline Variable & Factor loading $(\lambda)$ & Composite reliability (a) \\
\hline \multirow{6}{*}{$\begin{array}{l}\text { Functional Motivations } \\
\text { (FM) }\end{array}$} & 0.884 & \multirow{6}{*}{0.8947} \\
\hline & 0.798 & \\
\hline & 0.838 & \\
\hline & 0.867 & \\
\hline & 0.752 & \\
\hline & 0.698 & \\
\hline \multirow{4}{*}{$\begin{array}{l}\text { Convenience Based } \\
\text { Functional Motivations } \\
(\mathrm{CBFM})\end{array}$} & 0.886 & \multirow{4}{*}{0.8763} \\
\hline & 0.779 & \\
\hline & 0.865 & \\
\hline & 0.846 & \\
\hline \multirow{8}{*}{$\begin{array}{l}\text { Product Motivations } \\
(\mathrm{PM})\end{array}$} & 0.843 & \multirow{8}{*}{0.8635} \\
\hline & 0.756 & \\
\hline & 0.652 & \\
\hline & 0.698 & \\
\hline & 0.794 & \\
\hline & 0.896 & \\
\hline & 0.837 & \\
\hline & 0.798 & \\
\hline \multirow{8}{*}{$\begin{array}{l}\text { Service Motivations } \\
\text { (SM) }\end{array}$} & 0.968 & \multirow{8}{*}{0.8839} \\
\hline & 0789 & \\
\hline & 0.689 & \\
\hline & 0.810 & \\
\hline & 0.894 & \\
\hline & 0.739 & \\
\hline & 0.759 & \\
\hline & 0.823 & \\
\hline
\end{tabular}

In addition, central tendency and dispersion measures were analyzed. The means score for constructs for purchasers ranges between 3.336 and 3.504 and for non-purchasers between 2.446 and 2.987 (Table 4).

A correlation analysis was used to measure the strength of the direction of an established linear relationship between constructs. Multiple regressions were used to test the hypotheses to evaluate the causal relationship between different motivational factors and construct and the intention to purchase using mobile applications. 
Table 4. Descriptive statistics for motivational constructs

\begin{tabular}{|c|c|c|c|c|c|}
\hline Construct & $\begin{array}{l}\text { No. of } \\
\text { Items }\end{array}$ & Buyer and Non-buyer & Mean & $\begin{array}{c}\text { Std. } \\
\text { Deviation }\end{array}$ & $\mathbf{N}$ \\
\hline \multirow{2}{*}{$\begin{array}{l}\text { Functional Motivations } \\
\text { (FM) }\end{array}$} & \multirow{2}{*}{6} & Buyer & 3.435 & 0.9843 & 120 \\
\hline & & Non-buyer & 2.446 & 1.125 & 120 \\
\hline \multirow{2}{*}{$\begin{array}{l}\text { Convenience Based } \\
\text { Functional Motivations } \\
\text { (CBFM) }\end{array}$} & \multirow[b]{2}{*}{4} & Buyer & 3.456 & 1.0543 & 120 \\
\hline & & Non-buyer & 2.987 & 0.8944 & 120 \\
\hline \multirow{2}{*}{ Product Motivations (PM) } & \multirow{2}{*}{8} & Buyer & 3.336 & 0.9383 & 120 \\
\hline & & Non-buyer & 2.567 & 0.9765 & 120 \\
\hline \multirow{2}{*}{ Service Motivations (SM) } & \multirow{2}{*}{8} & Buyer & 3.504 & 1.1418 & 120 \\
\hline & & Non-buyer & 2.789 & 1.3949 & 120 \\
\hline
\end{tabular}

\section{Research findings}

\section{a. Functional motivations}

Principal factor analysis grouped functional motivations into two groups: Functional Motivation and Convenience Based Functional Motivation. A regression analysis was conducted in these two groups. We found that the constructed factors explain $99 \%$ of the variance of the construct. Results are presented in Table 5. The findings indicate that the primary concern of non-users is that the usage and practicality of mobile applications to purchase a ticket are confusing, and they still prefer their old channel.

Table 5. Functional motivations on mobile purchase behavior

\begin{tabular}{|c|c|c|c|c|c|}
\hline & $\begin{array}{l}\text { Buyer and } \\
\text { non-buyer }\end{array}$ & $\mathrm{R}$ & R squared & $\mathrm{F}$ & Sig. \\
\hline & Buyer & 0.999 & 0.990 & 45.768 & .000 \\
\hline & Non-buyer & 0.699 & 0.489 & 46.695 & .000 \\
\hline $\begin{array}{l}\text { Functional Motivations } \\
\text { (FM) }\end{array}$ & & $\begin{array}{l}\text { Item Total } \\
\text { Correlation }\end{array}$ & $\begin{array}{l}\text { Standardized } \\
\text { Coefficients } \\
\text { (Beta) }\end{array}$ & $\mathrm{t}$ & Sig. \\
\hline \multirow{2}{*}{$\begin{array}{l}\text { Understanding and usage of } \\
\text { application is easy }\end{array}$} & Buyer & .867 & 0.139 & 109.495 & .000 \\
\hline & Non-buyer & .098 & 0.428 & .199 & .419 \\
\hline \multirow{2}{*}{$\begin{array}{l}\text { Application has no lag or } \\
\text { bug }\end{array}$} & Buyer & .856 & 0.135 & 57.461 & .000 \\
\hline & Non-buyer & .793 & 0.135 & $34 \cdot 354$ & .000 \\
\hline \multirow{2}{*}{$\begin{array}{l}\text { I can easily find the } \\
\text { information I need }\end{array}$} & Buyer & .821 & 0.142 & 45.693 & .000 \\
\hline & Non-buyer & .694 & 0.245 & 57.397 & .037 \\
\hline \multirow{2}{*}{$\begin{array}{l}\text { User-generated content } \\
\text { helps to choose the best } \\
\text { movie }\end{array}$} & Buyer & .855 & 0.148 & 37.586 & .000 \\
\hline & Non-buyer & .810 & 0.172 & 41.498 & .001 \\
\hline \multirow{2}{*}{$\begin{array}{l}\text { Watching movie trailers } \\
\text { help me choose a good } \\
\text { movie }\end{array}$} & Buyer & .862 & 0.169 & $145 \cdot 596$ & .000 \\
\hline & Non-buyer & .793 & 0.248 & 137.837 & .000 \\
\hline
\end{tabular}


It is easy to buy the ticket, choose seats and complete the money transaction

\begin{tabular}{ccccc} 
Buyer & .681 & 0.151 & 71.894 & .000 \\
\hline Non-buyer & .954 & 0.239 & 75.234 & .000
\end{tabular}

The second group of factors is convenience-based functional motivations. Findings are illustrated in Table 6. These factors are also in line with the previous one. Non-users are less prone to use the mobile application because they find it complicated or confusing to work with. They understand the concept of the availability of a mobile application and find it time-saving. Still, they also see the old-fashioned process of purchasing at movie theaters as more assuring.

Table 6. Convenience based functional motivations on mobile purchase behavior

\begin{tabular}{lccccc}
\hline & $\begin{array}{c}\text { Buyer and } \\
\text { non-buyer }\end{array}$ & $\mathrm{R}$ & $\mathrm{R}$ squared & $\mathrm{F}$ & Sig. \\
\cline { 2 - 6 } & Buyer & .724 & .691 & 145.435 & .000 \\
\cline { 2 - 6 } & Non-buyer & .786 & .703 & 167.344 & .000 \\
\hline $\begin{array}{l}\text { Convenience Based } \\
\text { Functional Motivations } \\
\text { (CBFM) }\end{array}$ & & $\begin{array}{c}\text { Item Total } \\
\text { Correlation }\end{array}$ & $\begin{array}{c}\text { Standardized } \\
\text { Coefficients } \\
\text { (Beta) }\end{array}$ & $\mathrm{t}$ & Sig. \\
\hline $\begin{array}{l}\text { Mobile shopping helps me } \\
\text { save time }\end{array}$ & Buyer & 0.911 & 0.318 & 98.032 & .000 \\
\hline $\begin{array}{l}\text { Application is always } \\
\text { available }\end{array}$ & Non-buyer & 0.893 & 0.345 & 119.245 & .000 \\
\hline $\begin{array}{l}\text { I can easily print my tickets } \\
\text { when I come to the movie } \\
\text { theater }\end{array}$ & Buyer & 0.906 & 0.312 & 118.543 & .000 \\
\hline & Non-buyer & 0.950 & 0.345 & 154.245 & .039 \\
\hline $\begin{array}{l}\text { The whole process is very } \\
\text { convenient for me }\end{array}$ & Buyer & 0.768 & 0.273 & 149.345 & .000 \\
\hline & Non-buyer & 0.596 & 0.304 & 153.546 & .048 \\
\hline
\end{tabular}

In general, these results show that the utilitarian features of functional motivation significantly impact consumer motivation to buy tickets through mobile applications. Therefore, these factors must be considered in designing the application, user interface, user experience, and content to induce more consumers to consider this channel to purchase tickets.

\section{b. Product motivations}

Table 7 shows the results of the analysis on product motivations. Availability of tickets leads to an opportunity of going to a movie theater which otherwise seemed unlikely. Also, this availability increases the rate of purchase. This motivates consumers to buy more tickets. As for non-users, they tend to continue the traditional process of purchasing at movie theaters. Another point that is highlighted here again is that non-users do not fully 
trust the process of buying and printing, probably due to their unfamiliarity with technology or simply because they have not experienced purchase through the mobile channel. All these factors have a significant impact on consumer motivation.

Further findings show that the wide variety of available movie and movie theaters encourages consumers to buy a ticket for another movie at another movie theater if their desired movie is entirely sold out at their desired destination. Hence it can be asserted that motivational features of this component significantly act as moderators.

Table 7. Product motivations

\begin{tabular}{|c|c|c|c|c|c|}
\hline & $\begin{array}{l}\text { Buyer and } \\
\text { non-buyer }\end{array}$ & $\mathrm{R}$ & R squared & $\mathrm{F}$ & Sig. \\
\hline & Buyer & .798 & .769 & 108.304 & .000 \\
\hline & Non-buyer & .714 & .671 & 154.143 & .000 \\
\hline $\begin{array}{l}\text { Product Motivations } \\
\text { (PM) }\end{array}$ & & $\begin{array}{l}\text { Item Total } \\
\text { Correlation }\end{array}$ & $\begin{array}{l}\text { Standardized } \\
\text { Coefficients } \\
\text { (Beta) }\end{array}$ & $\mathrm{t}$ & Sig. \\
\hline \multirow{2}{*}{ I can buy a ticket for all movies } & Buyer & 0.889 & 0.314 & 55.698 & .000 \\
\hline & Non-buyer & 0.930 & 0.340 & 47.234 & .000 \\
\hline \multirow{2}{*}{$\begin{array}{l}\text { I can buy tickets for all movie } \\
\text { theaters }\end{array}$} & Buyer & 0.823 & 0.288 & 210.345 & .000 \\
\hline & Non-buyer & 0.987 & 0.357 & 229.875 & .000 \\
\hline \multirow{2}{*}{$\begin{array}{l}\text { I know when I buy tickets with my } \\
\text { mobile, I can print them easily at } \\
\text { destination }\end{array}$} & Buyer & 0.846 & 0.298 & 156.546 & .000 \\
\hline & Non-buyer & 0.679 & 0.198 & 139.764 & .586 \\
\hline \multirow{2}{*}{$\begin{array}{l}\text { The fact that I can buy tickets } \\
\text { anytime at anywhere is very } \\
\text { pleasing }\end{array}$} & Buyer & 0.887 & 0.257 & 126.456 & .000 \\
\hline & Non-buyer & 0.975 & 0.387 & 187.850 & .000 \\
\hline \multirow{2}{*}{$\begin{array}{l}\text { When my first choice of movie is } \\
\text { not available, I consider other } \\
\text { options }\end{array}$} & Buyer & 0.897 & 0.379 & $167 \cdot 345$ & .000 \\
\hline & Non-buyer & 0.834 & 0.487 & $154 \cdot 345$ & .000 \\
\hline \multirow{2}{*}{$\begin{array}{l}\text { If I can't buy tickets for some } \\
\text { movie theater on my mobile, I will } \\
\text { not go and buy personally }\end{array}$} & Buyer & 0.849 & 0.398 & 122.454 & .000 \\
\hline & Non-buyer & 0.630 & 0.495 & 126.356 & .146 \\
\hline \multirow{2}{*}{$\begin{array}{l}\text { When my first choice of a movie } \\
\text { theater is not available, I consider } \\
\text { other options }\end{array}$} & Buyer & 0.864 & 0.385 & 46.345 & .000 \\
\hline & Non-buyer & 0.919 & 0.345 & $59 \cdot 345$ & .000 \\
\hline \multirow{2}{*}{$\begin{array}{l}\text { Quality of purchase through } \\
\text { mobile application pleases me }\end{array}$} & Buyer & 0.798 & 0.445 & 87.345 & .000 \\
\hline & Non-buyer & - & - & - & - \\
\hline
\end{tabular}

\section{c. Service motivations}

The fact that consumers receive a purchase code immediately after their transaction is assuring and significantly affects consumer motivation. It is understood that non-users are concerned whether they understand the mobile application or not. But it can be derived from results that these factors positively impact consumer motivation (Table 8). 
Table 8. Service motivations

\begin{tabular}{|c|c|c|c|c|c|}
\hline & $\begin{array}{l}\text { Buyer and } \\
\text { non-buyer }\end{array}$ & $\mathrm{R}$ & R squared & $\mathrm{F}$ & Sig. \\
\hline & Buyer & .887 & .679 & 287.005 & .000 \\
\hline & Non-buyer & .561 & .489 & 240.649 & .000 \\
\hline $\begin{array}{l}\text { Service Motivations } \\
\text { (SM) }\end{array}$ & & $\begin{array}{l}\text { Item Total } \\
\text { Correlation }\end{array}$ & $\begin{array}{l}\text { Standardized } \\
\text { Coefficients } \\
\text { (Beta) }\end{array}$ & $\mathrm{t}$ & Sig. \\
\hline \multirow{2}{*}{$\begin{array}{l}\text { The process of purchase in the } \\
\text { application is smooth and } \\
\text { flawless }\end{array}$} & Buyer & 0.656 & 0.571 & 78.045 & .000 \\
\hline & Non-buyer & 0.982 & 0.648 & 92.484 & .000 \\
\hline \multirow{2}{*}{$\begin{array}{l}\text { I know this application helps me } \\
\text { to buy tickets every time I decide } \\
\text { to go to movies }\end{array}$} & Buyer & 0.857 & 0.502 & 112.454 & .000 \\
\hline & Non-buyer & 0.935 & 0.738 & 143.875 & .000 \\
\hline \multirow{2}{*}{$\begin{array}{l}\text { The fact that I can print my } \\
\text { tickets as soon as I arrive at a } \\
\text { movie theater is assuring }\end{array}$} & Buyer & 0.621 & 0.546 & 108.543 & .000 \\
\hline & Non-buyer & 0.983 & 0.458 & 149.245 & .000 \\
\hline \multirow{2}{*}{$\begin{array}{l}\text { The fact that the purchase code is } \\
\text { sent to my mobile immediately is } \\
\text { assuring }\end{array}$} & Buyer & 0.798 & 0.456 & 125.345 & .000 \\
\hline & Non-buyer & 0.842 & 0.484 & 147.284 & .000 \\
\hline \multirow{2}{*}{$\begin{array}{l}\text { All the features of the application } \\
\text { are understandable to me }\end{array}$} & Buyer & 0.825 & 0.484 & 150.345 & .000 \\
\hline & Non-buyer & 0.578 & 0.398 & 124.234 & .678 \\
\hline \multirow{2}{*}{$\begin{array}{l}\text { I have always received the } \\
\text { purchase code }\end{array}$} & Buyer & 0.698 & 0.594 & 156.564 & .000 \\
\hline & Non-buyer & - & - & - & - \\
\hline \multirow{2}{*}{$\begin{array}{l}\text { In case of trouble, a call center is } \\
\text { always available }\end{array}$} & Buyer & 0.778 & 0.498 & 146.345 & .000 \\
\hline & Non-buyer & - & - & - & - \\
\hline \multirow{2}{*}{$\begin{array}{l}\text { In a movie theater, the print } \\
\text { stand is easy to find and } \\
\text { understandable to work with }\end{array}$} & Buyer & 0.809 & 0.534 & 167.345 & .000 \\
\hline & Non-buyer & - & - & - & - \\
\hline
\end{tabular}

\section{d. Gender and media selection}

To examine the relationship between gender motivational factors, descriptive and dispersions analysis and independent t-test was conducted. The results showed that there is no significant difference between male and female consumers for all factors and constructs. These findings prove that utilitarian features are equally important to both genders (Table 9). 
Table 9. Comparative analysis of motivational factors based on gender

\begin{tabular}{|c|c|c|c|c|c|c|c|c|}
\hline Construct & Gender & $\begin{array}{c}\text { Buyer } \\
\text { Non-buyer }\end{array}$ & Mean & SD & $\mathrm{F}$ & Sig (p). & t-value & $\begin{array}{c}\text { Sig } \\
(2- \\
\text { tailed) }\end{array}$ \\
\hline \multirow{4}{*}{$\begin{array}{l}\text { Functional } \\
\text { Motivations } \\
\text { (FM) }\end{array}$} & \multirow[t]{2}{*}{ Male } & Non-buyer & 3.54 & .9857 & \multirow[b]{2}{*}{1.875} & \multirow[b]{2}{*}{.212} & \multirow[b]{2}{*}{.562} & \multirow[b]{2}{*}{.567} \\
\hline & & Buyer & 3.48 & .8395 & & & & \\
\hline & \multirow[t]{2}{*}{ Female } & Non-buyer & 3.57 & 1.0945 & \multirow{2}{*}{.142} & \multirow{2}{*}{.630} & \multirow{2}{*}{.377} & \multirow{2}{*}{.771} \\
\hline & & Buyer & 3.54 & 1.0791 & & & & \\
\hline \multirow{4}{*}{$\begin{array}{l}\text { Product } \\
\text { Motivations } \\
\text { (PM) }\end{array}$} & \multirow[t]{2}{*}{ Male } & Non-buyer & 3.55 & 1.0985 & \multirow{2}{*}{2.426} & \multirow[b]{2}{*}{.120 } & \multirow{2}{*}{.569} & \multirow{2}{*}{.610} \\
\hline & & Buyer & 3.46 & .9456 & & & & \\
\hline & \multirow[t]{2}{*}{ Female } & Non-buyer & 3.43 & .9845 & \multirow{2}{*}{1.940} & \multirow{2}{*}{.548} & \multirow{2}{*}{.798} & \multirow{2}{*}{.470} \\
\hline & & Buyer & 3.54 & .9537 & & & & \\
\hline \multirow{4}{*}{$\begin{array}{l}\text { Service } \\
\text { Motivations } \\
\text { (SM) }\end{array}$} & \multirow[t]{2}{*}{ Male } & Non-buyer & 3.29 & .7836 & \multirow{2}{*}{3.472} & \multirow{2}{*}{.089} & \multirow{2}{*}{.340} & \multirow{2}{*}{.814} \\
\hline & & Buyer & 3.27 & .6739 & & & & \\
\hline & \multirow[t]{2}{*}{ Female } & Non-buyer & 3.26 & .4840 & \multirow{2}{*}{5.938} & \multirow{2}{*}{.152} & \multirow{2}{*}{.145} & \multirow{2}{*}{.675} \\
\hline & & Buyer & 3.28 & .5839 & & & & \\
\hline
\end{tabular}

\section{Theoretical discussions and practical implications}

Theoretically, this study contributes to the comparison of utilitarian features between users and non-users. In doing so, features such as functional, service, and product motivations were taken into account. No comprehensive study has compared users and non-users based on these features and motivations. These factors are more accurate than other traditional factors such as demographic or socioeconomic ones. These findings are in line with similar results of (Hwang \& Jeong, 2016). Hence, in comparing users and non-users, this study provides a novel perspective from the existing literature.

This study has found that product motivation, which is manifested in availability through application purchase, leads to an increase in the rate and amount of purchase. These findings confirm Yang and Kim (2012) that the right product at the right time may raise purchase motivation among the consumer. Thus, we can say that availability through online applications can stimulate this kind of sense: finding the right product at the right time. Also, the nature of the product, namely the cinema ticket, will bring about the sense of security of the purchase; they do not need to worry about the quality of the product they have bought through online application. They know that "they get what they buy" (Perea y Monsuwé et al., 2004).

Interestingly, this study has also found that non-users, even if they want to purchase through application, do not trust the process. On the one side, it confirms the Technology Acceptance Model (TAM) thesis that the easy-use and user-friendly technologies will increase 
the potentiality of their adoption by the consumers (Dabholkar \& Bagozzi, 2002; Davis et al., 1989; Perea y Monsuwé et al., 2004). On the other side, this study has shown that trust is another important factor influencing the adoption of new technologies.

This study has also shown that information plays a central role in the purchase process. One of the main features of online purchase sites and applications is providing information. This relation has been subject to study before, and there is a positive relationship between information and motivation for online buying (Joines J. L et al., 2003; Korgaonkar \& Wolin, 1999). Further findings suggest that service is more information sensitive rather than product (Rajamma et al., 2007). In the case of a cinema ticket, the information provided through the application gives consumers helpful information, such as the availability of tickets for a particular movie or even the availability of parking lots.

This study also has an interesting finding related to gender issues that could be the basis for further empirical studies. Principally, the result supports the idea that gender plays no role in the process. It is somewhat different from some previous studies, which have argued that different factors influence men and women differently in mobile shopping (Bigne et al., 2005; Hahn \& Kim, 2013)

This study shows an emerging trend in purchase methods in the Iranian cinema context, which may apply to other recreational industries. The findings of this study, along with marketing communication practices, might help companies have a better and more persuasive interaction with their consumers through mobile channels. This knowledge of consumer behavior might help to improve the features and processes of mobile applications.

Additionally, this study shows that the availability of other options, information and being able to buy tickets at any time is critical even for non-users. The functional motivations have shown that information provided through the application might motivate consumers to purchase tickets. This emphasizes the content provided by the marketing communication managers. Additionally, mobile application users might decide to buy tickets spontaneously for movie theaters. If it were not available through the mobile application, they would not buy otherwise, but non-users would purchase at the place. Also, compared to buying at movie theaters, the availability of other movies and movie theaters motivated consumers to consider other options.

Online purchases might seem complex to some consumers, especially to non-users. The main point about non-users that communication managers must remember is that they might not use the application simply because they find it complicated or untrusting. They prefer paper tickets, and their primary concern is about printing tickets at movie theaters. Therefore, in marketing communications targeting non-users, ease of use, the ability of printing at movie theaters, and application features must be addressed in detail. 


\section{Conclusion}

This study's main objective is to conceptualize and investigate the moderating role of utilitarian features of mobile applications and the consequent effects on consumer motivations among users and non-users of mobile applications. Previous findings on factors affecting consumers' motivation to use mobile shopping are fragmented. The utilitarian domain seems to be neglected because the fact that consumers will use mobile applications is taken for granted. The empirically established evidence should shed some light on motivational factors which induce consumers to use this channel.

As motivational behavior of consumers affects their outcome behavior, it is important to fully understand the moderate roles of different aspects of motivational constructs and their barriers. This paper tried to examine this gap in the Iranian market. This study is an effort to understand how utilitarian features of a mobile application moderate purchase motivations and intentions among users and non-users. It is found that conceptualized factors, namely functional, product, and service motivations, significantly affect consumers' motivations, both male and female consumers. Thus, these factors should be considered in formulating marketing communication strategy and channel management, especially for non-users. This paper can be a bedrock for other researchers to take into account other motivational factors such as hedonic motivations, attitude, and situational factors to further our understanding of this domain.

This study has only examined one product, namely cinema tickets. Thus, further research may broaden this array by comparing several applications, such as air tickets and hoteling services. Future studies across different products might assist our understanding of consumer motivation in mobile shopping and mobile channel in general. This paper is about the adoption of the mobile channel over other media to purchase tickets based on a comparison between users and non-users. Another interesting topic for further research is examining the moderating effects of mobile shopping on choosing movies as a recreational activity among other options with the perspective of uses and gratifications traditions.

\section{Notes on contributors}

Emad Rahmanian is a lecturer at the Department of Management, Faculty of Management and Accounting, University of Tehran,

Tehran, Iran. Email: emad.rahmanian@,ut.ac.ir

Hassan Abolmolouki is a lecturer at the Department of Management, Faculty of Management and Accounting, University of Tehran, Tehran, Iran. Email: abolmolouki@ut.ac.ir 


\section{References}

Alba, J., Lynch, J., Weitz, B., Janiszewski, C., Lutz, R., Sawyer, A., \& Wood, S. (1997). Interactive home shopping: Consumer, retailer, and manufacturer incentives to participate in electronic marketplaces. Journal of Marketing, 61(3), 38. https://doi.org/10.2307/1251788

Alreck, P., \& Settle, R. B. (2002). Gender effects on internet, catalogue and store shopping. Journal of Database Marketing and Customer Strategy Management, 9(2), 150-162.

Ansari, A., Mela, C. F., \& Neslin, S. A. (2008). Customer channel migration. Journal of Marketing Research, 45(1), 60-76. https://doi.org/10.1509/jmkr.45.1.60

Arnold, M. J., \& Reynolds, K. E. (2003). Hedonic shopping motivations. Journal of Retailing, 79(2), 77-95. https://doi.org/10.1016/Soo22-4359(03)00007-1

Babin, B. J., Darden, W. R., \& Griffin, M. (1994). Work and/or fun: Measuring hedonic and utilitarian shopping value. Journal of Consumer Research, 20(4), 644-656.

http://www.jstor.org/stable/2489765

Bhatnagar, A., Misra, S., \& Rao, H. R. (2000). On risk, convenience, and internet shopping behavior. Communications of the ACM, 43(11), 98-105.

Bigne, E., Ruiz, C., \& Sanz, S. (2005). The impact of internet user shopping patterns and demographics on consumer mobile buying behaviour. Journal of Electronic Commerce, 6, 193209. http://citeseerx.ist.psu.edu/viewdoc/summary?doi=10.1.1.85.8738

Bloch, P. H., \& Bruce, G. D. (1984). Product involvement as leisure behavior. In T. C. Kinnear (Ed.), Advances in Consumer Research (pp. 197-202). Association for Consumer Research.

Bolton, R., \& Saxena-Iyer, S. (2009). Interactive services: A framework, synthesis and research directions. Journal of Interactive Marketing, 23(1), 91-104.

https://doi.org/10.1016/j.intmar.2008.11.002

Burke, R. R. (2002). Technology and the customer interface: What consumers want in the physical and virtual store. Journal of the Academy of Marketing Science, 3o(4), 411-432.

https://doi.org/10.1177/009207002236914

Childers, T. L., Carr, C. L., Peck, J., \& Carson, S. (2001). Hedonic and utilitarian motivations for online retail shopping behavior. Journal of Retailing, 77(4), 511-535.

https://doi.org/10.1016/Soo22-4359(01)00056-2

Clarke III, I. (2001). Emerging value propositions for M-Commerce. Journal of Business Strategies, 25(2), 41-57. https://doi.org/10.54155/jbs.25.2.41-57

Dabholkar, P. A., \& Bagozzi, R. P. (2002). An attitudinal model of technology-based self-service: Moderating effects of consumer traits and situational factors. Journal of the Academy of Marketing Science, 30(3), 184-201. https://doi.org/10.1177/0092070302303001

Davis, F. D., Bagozzi, R. P., \& Warshaw, P. R. (1989). User acceptance of computer technology: A comparison of two theoretical models. Management Science, 35(8), 982-1003. https://doi.org/10.1287/mnsc.35.8.982

Deighton, J., \& Kornfeld, L. (2009). Interactivity's unanticipated consequences for markets and marketing. Journal of Interactive Marketing, 23, 2-12. 
Demirkan, H., \& Spohrer, J. (2014). Developing a framework to improve virtual shopping in digital malls with intelligent self-service systems. Journal of Retailing and Consumer Services, 21(5), 860-868. https://doi.org/10.1016/j.jretconser.2014.02.012

Denk, M., \& Hackl, M. (2004). Where does mobile business go? International Journal of Electronic Business, 2(5), 480.

Donthu, N., \& Garcia, A. (1999). The internet shopper. Journal of Advertising Research, 39(3), 5252.

Elastick, M. A., \& Feinberg, R. A. (1999). Shopping motives for mail catalog shopping. Journal of Business Research, 45(3), 281-290.

Evanschitzky, H., Iyer, G. R., Hesse, J., \& Ahlert, D. (2004). E-satisfaction: A re-examination. Journal of Retailing, 8o(3), 239-247. https://doi.org/10.1016/j.jretai.2004.08.002

Fischer, E., \& Arnold, S. J. (1990). More than a labor of love: Gender roles and christmas gift shopping. Journal of Consumer Research, 17(3), 333-345. https://doi.org/10.1086/208561

Foucault, B. E., \& Scheufele, D. A. (2002). Web vs campus store? Why students buy textbooks online. Journal of Consumer Marketing, 19(5), 409-423. https://doi.org/10.1108/07363760210437632

Frasquet, M., Mollá, A., \& Ruiz, E. (2015). Identifying patterns in channel usage across the search, purchase and post-sales stages of shopping. Electronic Commerce Research and Applications, 14(6), 654-665. https://doi.org/10.1016/j.elerap.2015.10.002

Gerbing, D. W., \& Anderson, J. C. (1988). An updated paradigm for scale development incorporating unidimensionality and its assessment. Journal of Marketing Research, 25(2), 186-192. https://doi.org/10.2307/3172650

Grewal, D., Gopalkrishnan, R. I., Krishnan, R., \& Sharma, A. (2003). The internet and the price-value chain. Journal of Business Research, 56(5), 391-398.

Groß, M. (2015). Mobile shopping: A classification framework and literature review. International Journal of Retail \& Distribution Management, 43(3), 221-241. https://doi.org/10.1108/IJRDM-06-2013-0119

Hahn, K. H. Y., \& Kim, J. (2013). Salient antecedents of mobile shopping intentions: Media dependency, fashion/brand interest and peer influence. Journal of Global Fashion Marketing, 4(4), 225-246. https://doi.org/10.1080/20932685.2013.817140

Heinonen, K., \& Pura, M. (2006). Classifying mobile services. In Helsinki Mobility Roundtable (pp. 12).

Hinz, O., Skiera, B., Barrot, C., \& Becker, J. U. (2011). Seeding strategies for viral marketing: An empirical comparison. Journal of Marketing, 75(6), 55-71. https://doi.org/10.1509/jm.10.0o88

Hirschman, E. C., \& Holbrook, M. B. (1982). Hedonic consumption: Emerging concepts, methods and propositions. Journal of Marketing, 46(3), 92. https://doi.org/10.2307/1251707

Holmes, A., Byrne, A., \& Rowley, J. (2013). Mobile shopping behaviour: Insights into attitudes, shopping process involvement and location. International Journal of Retail \& Distribution Management, 42(1), 25-39. https://doi.org/10.1108/IJRDM-10-2012-0096

Huang, L., Lu, X., \& Ba, S. (2016). An empirical study of the cross-channel effects between web and mobile shopping channels. Information \& Management, 53(2), 265-278. https://doi.org/10.1016/j.im.2015.10.006 
Hung, M.-C., Yang, S.-T., \& Hsieh, T.-C. (2012). An examination of the determinants of mobile shopping continuance. Int. J. Electron. Bus. Manag., 10, 29-37.

Hwang, Y., \& Jeong, J. (2016). Electronic commerce and online consumer behavior research. Information Development, 32(3), 377-388. https://doi.org/10.1177/0266666914551071

Joines J. L, Scherer C. W, \& Scheufele D. A. (2003). Exploring motivations for consumer Web use and their implications for e-commerce. Journal of Consumer Marketing, 20, 90-108(19).

Keen, C., Wetzels, M., de Ruyter, K., \& Feinberg, R. (2004). E-tailers versus retailers: Which factors determine consumer preferences? Journal of Business Research, 57(7), 685-695. https://doi.org/10.1016/So148-2963(02)00360-o

Kim, H.-S. (2006). Using hedonic and utilitarian shopping motivations to profile inner city consumers. Journal of Shopping Center Research, 3.

Korgaonkar, P. K., \& Wolin, L. D. (1999). A multivariate analysis of web usage. Journal of Advertising Research, 39(2), 53-68.

Kumar, A., \& Mukherjee, A. (2013). Shop while you talk: Determinants of purchase intentions through a mobile device. International Journal of Mobile Marketing, 8(1), 23-37.

Mathwick, C., Malhotra, N., \& Rigdon, E. (2001). Experiential value: Conceptualization, measurement and application in the catalog and internet shopping environment. Journal of Retailing, 77(1), 39-56. https://doi.org/10.1016/Soo22-4359(00)00045-2

Mohd Suki, N., Ramayah, T., \& Mohd Suki, N. (2008). Internet shopping acceptance. Direct Marketing: An International Journal, 2(2), 97-110. https://doi.org/10.1108/17505930810881752

Mort, G. S., \& Drennan, J. (2002). Mobile digital technology: Emerging issue for marketing. Journal of Database Marketing \& Customer Strategy Management, 10(1), 9-23. https://doi.org/10.1057/palgrave.jdm.3240090

Newman, C. L., Wachter, K., \& White, A. (2018). Bricks or clicks? Understanding consumer usage of retail mobile apps. Journal of Services Marketing, 32(2), 211-222. https://doi.org/10.1108/JSM-08-2016-0289

Pantano, E. (2014). Innovation drivers in retail industry. International Journal of Information Management, 34(3), 344-350. https://doi.org/10.1016/j.ijinfomgt.2014.03.002

Park, S., \& Lee, D. (2017). An empirical study on consumer online shopping channel choice behavior in omni-channel environment. Telematics and Informatics, 34(8), 1398-1407. https://doi.org/10.1016/j.tele.2017.06.003

Parsons, A. G. (2002). Non-functional motives for online shoppers: Why we click. Journal of Consumer Marketing, 19(5), 380-392. https://doi.org/10.1108/07363760210437614

Paul, C. L., Mee, K. J., Judd, T. M., Walsh, R. A., Tang, A., Penman, A., \& Girgis, A. (2010). Anywhere, anytime: Retail access to tobacco in New South Wales and its potential impact on consumption and quitting. Social Science \& Medicine, 71(4), 799-806.

https://doi.org/10.1016/j.socscimed.2010.05.011

Pedersen, P. E., Methlie, L. B., \& Thorbjornsen, H. (2002). Understanding mobile commerce end-user adoption: A triangulation perspective and suggestions for an exploratory service evaluation framework. Proceedings of the 35th Annual Hawaii International Conference on System Sciences, 8. https://doi.org/10.1109/HICSS.2002.994011 
Perea y Monsuwé, T., Dellaert, B. G. C., \& de Ruyter, K. (2004). What drives consumers to shop online? A literature review. International Journal of Service Industry Management, 15(1), 102121. https://doi.org/10.1108/09564230410523358

Rajamma, R. K., Paswan, A. K., \& Ganesh, G. (2007). Services purchased at brick and mortar versus online stores, and shopping motivation. Journal of Services Marketing, 21(3), 200-212. https://doi.org/10.1108/08876040710746552

Scarpi, D. (2005). Hedonic and utilitarian behaviour in specialty shops. The Marketing Review, 5(1), 31-44. https://doi.org/10.1362/1469347053294797

Shankar, V., \& Balasubramanian, S. (2009). Mobile marketing: A synthesis and prognosis. Journal of Interactive Marketing, 23(2), 118-129. https://doi.org/10.1016/j.intmar.2009.02.002

Sherry, J. F. (1990). A sociocultural analysis of a midwestern american flea market. Journal of Consumer Research, 17(1), 13. https://doi.org/10.1086/208533

Sherry, J. F., McGrath, M. A., \& Levy, S. J. (1993). The dark side of the gift. Journal of Business Research, 28(3), 225-244. https://doi.org/10.1016/0148-2963(93)90049-U

Sheth, J. (1983). An integrative theory of patronage preference and behavior. In W. R. Darden \& R. F. Lusch (Eds.), Patronage Behavior and Retail Management (pp. 9-28). Elsevier Science.

Tauber, E. M. (1972). Why do people shop? Journal of Marketing, 36(4), 46. https://doi.org/10.2307/1250426

Taylor, D. G., \& Levin, M. (2014). Predicting mobile app usage for purchasing and informationsharing. International Journal of Retail \& Distribution Management, 42(8), 759-774. https://doi.org/10.1108/IJRDM-11-2012-0108

Thomas, J. S., \& Sullivan, U. Y. (2005). Managing marketing communications with multichannel customers. Journal of Marketing, 69(4), 239-251. https://doi.org/10.1509/jmkg.2005.69.4.239

Tong, S., Luo, X., \& Xu, B. (2020). Personalized mobile marketing strategies. Journal of the Academy of Marketing Science, 48(1), 64-78. https://doi.org/10.1007/s11747-019-00693-3

Verhoef, P. C., Kannan, P. K., \& Inman, J. J. (2015). From multi-channel retailing to omni-channel retailing. Journal of Retailing, 91(2), 174-181. https://doi.org/10.1016/j.jretai.2015.02.005

Verhoef, P. C., Lemon, K. N., Parasuraman, A., Roggeveen, A., Tsiros, M., \& Schlesinger, L. A. (2009). Customer experience creation: Determinants, dynamics and management strategies. Journal of Retailing, 85(1), 31-41. https://doi.org/10.1016/j.jretai.2008.11.001

Wang, R. J.-H., Malthouse, E. C., \& Krishnamurthi, L. (2015). On the go: How mobile shopping affects customer purchase behavior. Journal of Retailing, 91(2), 217-234. https://doi.org/10.1016/j.jretai.2015.01.002

Westbrook, R. A., \& Black, W. C. (1985). A motivation-based shopper typology. Journal of Retailing, 61(1), 78-103.

Wolfinbarger, M., \& Gilly, M. C. (2001). Shopping online for freedom, control, and fun. California Management Review, 43(2), 34-55. https://doi.org/10.2307/41166074

Wu, J.-H., \& Hisa, T.-L. (2008). Developing e-business dynamic capabilities: An analysis of ecCommerce innovation from I-, M-, to U-commerce. Journal of Organizational Computing and Electronic Commerce, 18(2), 95-111. https://doi.org/10.1080/10919390701807525 
Wu, J.-H., \& Wang, S.-C. (2005). What drives mobile commerce? An empirical evaluation of the revised technology acceptance model. Information \& Management, 42(5), 719-729. https://doi.org/10.1016/j.im.2004.07.001

Yang, K. (2010). Determinants of US consumer mobile shopping services adoption: Implications for designing mobile shopping services. Journal of Consumer Marketing, 27(3), 262-270. https://doi.org/10.1108/07363761011038338

Yang, K., \& Kim, H. (2012). Mobile shopping motivation: An application of multiple discriminant analysis. International Journal of Retail \& Distribution Management, 4O(10), 778-789. https://doi.org/10.1108/09590551211263182 